\title{
Reactance and perceived disease severity as determinants of COVID-19 vaccination intention: An application of the theory of planned behavior
}

\author{
Dariusz Drążkowski \\ Radosław Trepanowski \\ Adam Mickiewicz University in Poznań
}

\begin{abstract}
$^{1}$
Vaccination is crucial in fighting the COVID-19 pandemic. To encourage as many people as possible to be vaccinated, it is essential to identify the determinants of COVID-19 vaccination intention. The present study aimed to do so through an application of the theory of planned behavior (TPB). We examined variables associated with TPB, perceived severity of COVID-19, knowing someone afflicted with COVID-19, and individual differences, such as age, gender, and psychological reactance, among 551 Polish participants. Attitude (utility beliefs) toward COVID-19 vaccination was the strongest predictor of vaccination intention, followed by beliefs about social norms and perceived behavioral control. Older age and knowing someone with COVID-19 led to higher vaccination intention through perceived higher severity of the infection, and higher levels of all TPB components, compared with other participants. Being a woman and having higher trait reactance negatively affected COVID-19 vaccination intention through lower levels of all TPB components. The results show that COVID-19 vaccination intention is directly determined by all TPB components, and is affected by gender, age, COVID-19-related variables, and reactance. Our results contribute to the scientific pursuit of encouraging uptake of the
\end{abstract}

\footnotetext{
${ }^{1}$ Abbreviations: AGFI, adjusted goodness of fit index; AVE, average variance extracted; CFA, confirmatory factor analysis; CFI, comparative fit index; GFI, goodness of fit index; HPRS, Hong Psychological Reactance Scale; HTMT, heterotrait-monotrait ratio of correlations; RMSEA, root mean square of error of approximation; SEM, structural equation modelling; SRMR, standardized root mean square residual; TLI, Tucker-Lewis index; TPB, theory of planned behavior; WLSM, weighted least squares-mean.
} 


\section{DETERMINANTS OF COVID-19 VACCINATIONS}

COVID-19 vaccine by identifying modifiable determinants that could be targeted in health promotion campaigns.

Keywords: COVID-19, theory of planned behavior, reactance, vaccination intention, disease severity 


\section{DETERMINANTS OF COVID-19 VACCINATION}

\section{Introduction}

Vaccination against COVID-19 is currently a worldwide priority, as it is a long-term solution to overcoming the ongoing pandemic (Yamey et al., 2020). While several effective and safe vaccines have recently been developed (Kim et al., 2021), the effectiveness of vaccination programs depends on high vaccine acceptance and social uptake, which may be hard to achieve, considering the high aversion to vaccination observed around the world. In Poland, for example, $27.8 \%$ of people did not want to be vaccinated against COVID-19 at the end of April 2021 (IRBIS, 2021). People's unwillingness to get vaccinated raises serious concerns about the achievability of herd immunity in some populations. Thus, it is crucial to develop evidence-based health communication, encouraging vaccination against COVID-19. Identifying the determinants of vaccination intention is vital for achieving this goal. Based on the theory of planned behavior (TPB; Ajzen, 1991), we aimed to comprehensively explain the motivations behind COVID-19 vaccination intention. We incorporated new determinants, such as trait reactance (Hornsey et al., 2018) and perceived severity of COVID-19 (Karlsson et al., 2020), in the examined model, to improve prediction of motivation for COVID-19 vaccination and define the conditions for effective vaccination persuasion.

\subsection{Underlying Vaccination Motivation}

TPB is a helpful theoretical framework for understanding an individual's underlying motivations for vaccination (Ajzen, 1991). It is particularly relevant to studies on COVID-19 vaccination as it helps identify the specific aspects of individual differences (e.g., attitudes) that guide intentional behavior. TPB has been widely applied to understand and predict intention to vaccinate, in both pre-pandemic (e.g., Agarwal, 2014) and pandemic conditions (e.g., Lueck \& Spiers, 2020). 


\section{DETERMINANTS OF COVID-19 VACCINATION}

According to TPB, intentions indicate the motivational factors that influence behavior (Ajzen, 1991). As per this theory, intentional behavior arises from three motivational belief systems about any given behavior: utility, social norm, and control beliefs. Utility beliefs focus on the consequences of the behavior and result in either an advantageous or disadvantageous attitude toward the behavior. Social norm beliefs are concerned with others' expectations of the behavior, and result in the establishment and reinforcement of social norms. Control beliefs are perceptions about the difficulty or effort required for executing a behavior and dealing with challenges, resulting in perceived behavioral control. All three belief systems indirectly affect behavior through intention.

Vaccination behavior potentially has a substantial impact on the welfare of others, in that it can protect them from contracting a severe disease, and can, therefore, be considered a behavioral manifestation of moral norms. An individual's moral norms are defined as the socially determined and validated values they attach to behavior (Manstead, 2000). Moral beliefs can work parallelly with TPB belief systems (Conner \& Armitage, 1998). Moral norms significantly predict vaccination intention when controlling for all TPB components (Juraskova et al., 2012).

TPB provides a guide for understanding behavioral motivation, but does not specify how and where beliefs originate. Background factors could provide critical information about motivational antecedents of behavioral, normative, control, and moral beliefs. Failing to account for possible antecedents of such beliefs ignores crucial information on individuals' likelihood to be vaccinated against COVID-19. In the current study, we selected several variables that we believe can help predict vaccination intention, ultimately aimed at developing effective communication strategies to promote vaccination in future. 


\section{DETERMINANTS OF COVID-19 VACCINATION}

\subsection{Reactance}

Encouraging vaccination against COVID-19 may lead to backfire effects in individuals prone to reactance (Dillard \& Shen, 2005). When freedom is threatened or lost, such people experience psychological reactance, a motivational state that drives freedom restoration (Brehm \& Brehm, 1981). State reactance is characterized by negative emotions, such as anger, and negative cognitions that motivate people to behave in a way that will allow them to restore their freedom (Dillard \& Shen, 2005). Reactance-prone individuals may react to vaccination campaigns with anger and express negative attitudes toward vaccines and medical authorities (Soveri et al., 2021), which may explain why reactance is linked with anti-vaccination attitudes (Hornsey et al., 2018) and rejection of the COVID-19 vaccination (Soveri et al., 2021).

To date, no study has tested how reactance is associated with individual TPB components to explain vaccination motivation. Dominant media messages encouraging vaccination may lead individuals experiencing high reactance to perceive vaccination as harmful and immoral, based on their tendency to take the opposite position (Dillard \& Shen, 2005); for example, reactance-prone individuals may believe that, since everyone says vaccination is beneficial and morally appropriate, it must be detrimental in reality. External pressure to vaccinate, on such individuals, may reduce their perceived behavioral control, which is strongly linked to autonomy (Fishbein \& Ajzen, 2010) — an essential concept for individuals prone to reactance (Dillard \& Shen, 2005). Relatives and friends perceiving high-reactant individuals as reluctant to submit to external pressures might expect that those individuals would be resistant to getting a vaccine against COVID-19; this may also affect social norm beliefs of high-reactant individuals. In sum, trait reactance is a potential predictor of all belief systems which, in turn, are linked to intention. 


\section{DETERMINANTS OF COVID-19 VACCINATION}

Perceived symptoms or disease severity are critical determinants of people's vaccination decisions (Thomson et al., 2016); perceived severity of COVID-19 has been associated with willingness to be vaccinated (Karlsson et al., 2020). While the relationship between perceived severity and intention to vaccinate against it is well recognized, there is lack of research on whether TPB components could mediate the relationship between perceived disease severity and intention to vaccinate. We expect perceptions of COVID-19 as a severe disease to affect all TPB components: those who perceive the disease as severe will regard vaccination to be more beneficial and moral, social norms to be more encouraging, and vaccination to be easier, compared with those perceiving the disease as not severe.

One approach to determining the role of perceived disease severity in intention to vaccinate according to the TPB model entails identifying potential antecedents of perceived disease severity. This approach has practical value as it helps identify groups of people who do not perceive a disease as severe and should be targeted for vaccination education. Younger people are less willing to be vaccinated, because they tend to not perceive COVID-19 as a severe disease (Karlsson et al., 2020; Schwarzinger et al., 2021). Furthermore, men consider COVID-19 to be a less severe disease than women, while also being more willing to be vaccinated (Li et al., 2020; Makhanova \& Shepherd, 2020). Vaccine hesitancy also significantly decreases when a person knows someone afflicted with COVID-19 (Schwarzinger et al., 2021). Knowing someone who has had COVID-19 is also associated with perceiving the disease as severe (Drążkowski et al., 2020).

In sum, age, gender, and knowing someone who has contracted the infection are potential predictors of perceiving COVID-19 as a severe disease which, in turn, should be associated with utility, control, social, and moral beliefs and intention to vaccinate against the infection. 


\section{DETERMINANTS OF COVID-19 VACCINATION}

\subsection{The Current Study}

Given that COVID-19 vaccination is a crucial, evidence-based behavior for minimizing transmission of the disease, the present study aimed to identify the determinants of COVID-19 vaccination through an application of TPB. Existing knowledge on TPB mechanisms lacks an adequate explanation of the relationship between reactance and COVID-19 vaccination intention; therefore, this study aimed to introduce trait reactance to motivational paths leading to COVID-19 vaccination intention into the TPB model. Additionally, the current study aimed to incorporate perceived COVID-19 severity and selected determinants (age, gender, and knowing someone afflicted with COVID-19) in the explanation of motivation to vaccinate against COVID-19, within the TPB model. We examined reactance, perceived disease severity, and its determinants in a single model to explain the motivation to vaccinate against COVID-19. Determining whether one or both variables simultaneously and significantly predict the intention to vaccinate will allow for complexity in the design of health campaigns to encourage population-wide vaccination.

Based on TPB and previous empirical results, we hypothesized that reactance-prone individuals would have a lower intention to vaccinate against COVID-19 than other individuals, as they perceived it to have lower utility, control, social, and moral value.. Moreover, we hypothesized that older people, men, and people who knew someone who had already contracted COVID-19 would perceive the disease to be more severe, compared to others, and that this would be associated with greater motivation to be vaccinated through higher levels of all TPB components. 
DETERMINANTS OF COVID-19 VACCINATION

\section{Methods}

\subsection{Participants}

The study was conducted by a Polish national research panel. A random quota sample was invited to participate, based on the demographic (gender and age) structure of 18-70-year-olds in Poland. All participants were rewarded for their participation with points exchangeable for rewards on the research panel's website. The survey was conducted with 551 participants from December 8 to 14,2020 , three weeks before the initiation of COVID-19 vaccination efforts in the country. The dataset is available for free download from the Open Science Framework (https://osf.io/t247k/?view_only=90c74a9b84cd4ac08b7eeeaf02d5598). Participant demographics are described in Supplementary Table 1S.

\subsection{Procedure}

This study forms a part of a larger research project aimed at improving vaccination intention; hence, data on variables other than those in the current study were also collected. The study was conducted in accordance with the Declaration of Helsinki and all its amendments. All participants provided informed consent prior to data collection.

\subsection{Measures}

English and Polish versions of the survey are provided in Supplementary File 1. Survey items were compiled as follows:

Severity of COVID-19 - Self-perceived danger and severity in the case of contracting COVID-19 was assessed with three items (e.g. "I think that COVID-19 is a severe and dangerous sickness") rated on a seven-point scale ( $1=$ "completely disagree" to $7=$ "completely agree"; $\alpha=$ 93). 


\section{DETERMINANTS OF COVID-19 VACCINATION}

Trait reactance - This component was measured using the shortened version of the Hong Psychological Reactance Scale (HPRS; Hong \& Faedda, 1996), consisting of 11 items (e.g. "I resist the attempts of others to influence me") rated on a seven-point scale ( $1=$ "completely false" to $7=$ "completely true"; $\alpha=.90)$.

Utility beliefs - Beliefs about the possible consequences of being vaccinated against COVID-19 were assessed with three seven-point bipolar adjective scales: "very stupid/very wise", "unprotective/protective", " very harmful/very beneficial" $(\alpha=.95)$.

Behavioral control (control beliefs) - Beliefs about control over receiving a vaccination when a free vaccine against COVID-19 becomes available were assessed with three items (e.g. "It's mostly up to me, whether I get vaccinated against COVID-19 when a vaccine becomes available")rated on seven-point bipolar scales $(1=$ "completely disagree/very hard/no control at all" to $7=$ "completely agree/very easy/full control; $\alpha=.68$; after excluding the second item due to non-significance, $\alpha=.75)$.

Social norm beliefs - Beliefs about the opinions that people important to participants may have about their vaccination intention, were assessed with three items (e.g. "Most of the people, who are of importance to me, would praise me for vaccinating against COVID-19") rated on a seven-point scale ( $1=$ "completely disagree" to $7=$ "completely agree"; $\alpha=97)$.

Moral norms - Beliefs about one's moral responsibilities related to COVID-19 vaccination were assessed with three items (e.g. "Getting vaccinated against COVID-19 should be a moral obligation for all people") rated on a seven-point scale ( 1 = "completely disagree" to $7=$ "completely agree"; $\alpha=.96)$.

Vaccination intention - Participants' intention to vaccinate against COVID-19 when a free vaccine becomes available was assessed with three items (e.g. "When the vaccine becomes 


\section{DETERMINANTS OF COVID-19 VACCINATION}

available - I will vaccinate myself") rated on a seven-point scale $(1=$ "completely false" to $7=$ " completely true"; $\alpha=.96)$.

\section{Results}

First, confirmatory factor analysis (CFA) was conducted in R (v4.0.2), using Lavaan library (R Core Team, 2020; Rossel, 2012), to explore the structure of the variables. Due to lack of normality (all p-values were significant in the K-S test), and the categorical nature of the variables, we decided to use the weighted least squares-mean (WLSM) estimation method, as it is the most effective method in such cases (Moshagen \& Musch, 2014). CFA results are presented in Supplementary Table 2S. We excluded one item from the control beliefs scale, as it was non-significant.

Next, we determined Spearman's rho correlations between all variables. The "no" and "don't know" responses for the Know variable were summed before calculating the correlations, as there was only one "don't know" response. According to the data presented in Supplementary Table 3S, some items had very high correlations. Thus, before conducting structural equation modelling (SEM), we explored the divergent validity of the measures with (1) Fornell and Larcker's (1981) criterion, and (2) heterotrait-monotrait ratio of correlations (HTMT; Hensler et al., 2015). The Fornell-Larcker criterion assumes that average variance extracted (AVE) values should not exceed squared correlations. According to Hensler et al. (2015), HTMT values should not exceed .85 when constructs differ significantly, or .9 if measured constructs are similar. We adopted the latter, as some measured constructs were similar. Instead of squared correlation values, we used the square root of AVE to simplify the calculations. As shown in Supplementary Table 4S, the scale measuring moral norm beliefs did not meet the HTMT criterion (Moral norms-Intention $_{\text {HTMT }}=.94$ ), and was excluded from further analyses. 


\section{DETERMINANTS OF COVID-19 VACCINATION}

\section{Figure 1}

\section{Complete SEM model}

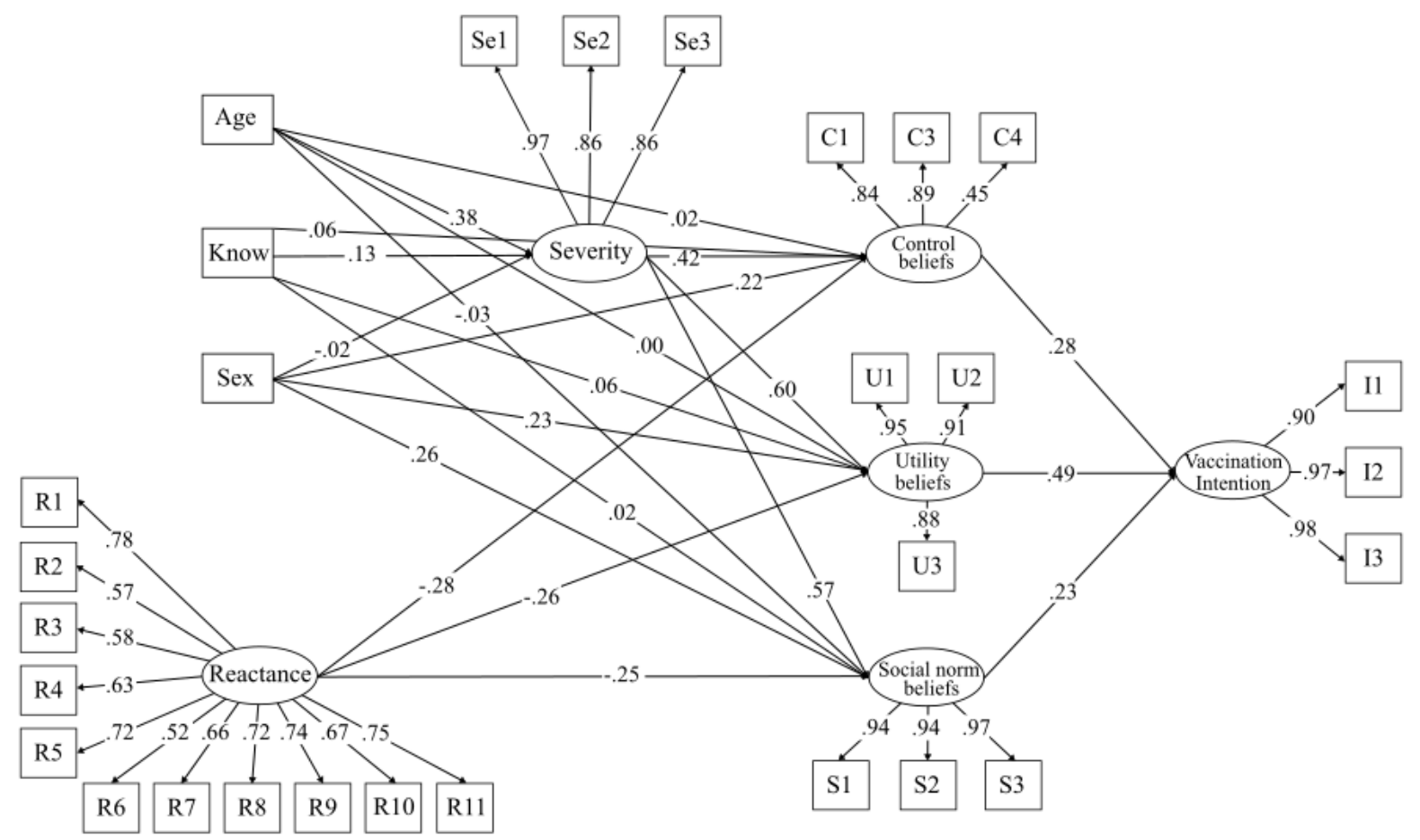

Note. Know $=$ Knowing someone afflicted with COVID-19

We also used the WLSM estimator in SEM. The complete model evaluating variables influencing vaccination intention (Figure 1) comprises three observed exogenous variables (gender, age, and knowing someone with COVID-19), one exogenous latent variable (psychological reactance), and five endogenous latent variables (perceived COVID-19 severity, utility, social norm, and control beliefs, and intention to vaccinate). We also estimated the error covariance among utility, social norm, and control beliefs in the model. Means, standard deviations and standardized factor loadings are presented in Supplementary Table 2S. 


\section{DETERMINANTS OF COVID-19 VACCINATION}

\section{Table 1}

Fit measurers

\begin{tabular}{lcc}
\hline Measure & Estimate & Cutoff* \\
\hline Tucker Lewis Index (TLI) & .965 & $>.90$ \\
Comparative Fit Index (CFI) & .969 & $>.90$ \\
Goodness of Fit Index (GFI) & 1.000 & $>.90$ \\
Adjusted Goodness of Fit Index (AGFI) & 1.000 & $>.90$ \\
Root Mean Square Error of Approximation (RMSEA) & .059 & $<.08$ \\
Standardized Root Mean Square Residual (SRMR) & .072 & $<.08$ \\
\hline
\end{tabular}

*Hu, \& Bentler, 1999; Steiger, 2007

We used the Tucker-Lewis index (TLI), comparative fit index (CFI), goodness of fit index (GFI), adjusted goodness of fit index (AGFI), root mean square of error of approximation (RMSEA), and the standardized root mean square residual (SRMR) to estimate the model fitness. Robust versions of the fit measures are reported in Table 1 and show that the model fits the data well. Chi ${ }^{2}$ was significant $\left(c h i^{2}=1929.84 d f=353, p>.001\right)$. Finally, we estimated direct, indirect, and total effects, presented in Supplementary Table 5S. Additionally, Figure 2 presents a simplified model with only significant values.

\section{Figure 2}

Simplified SEM model with significant values only

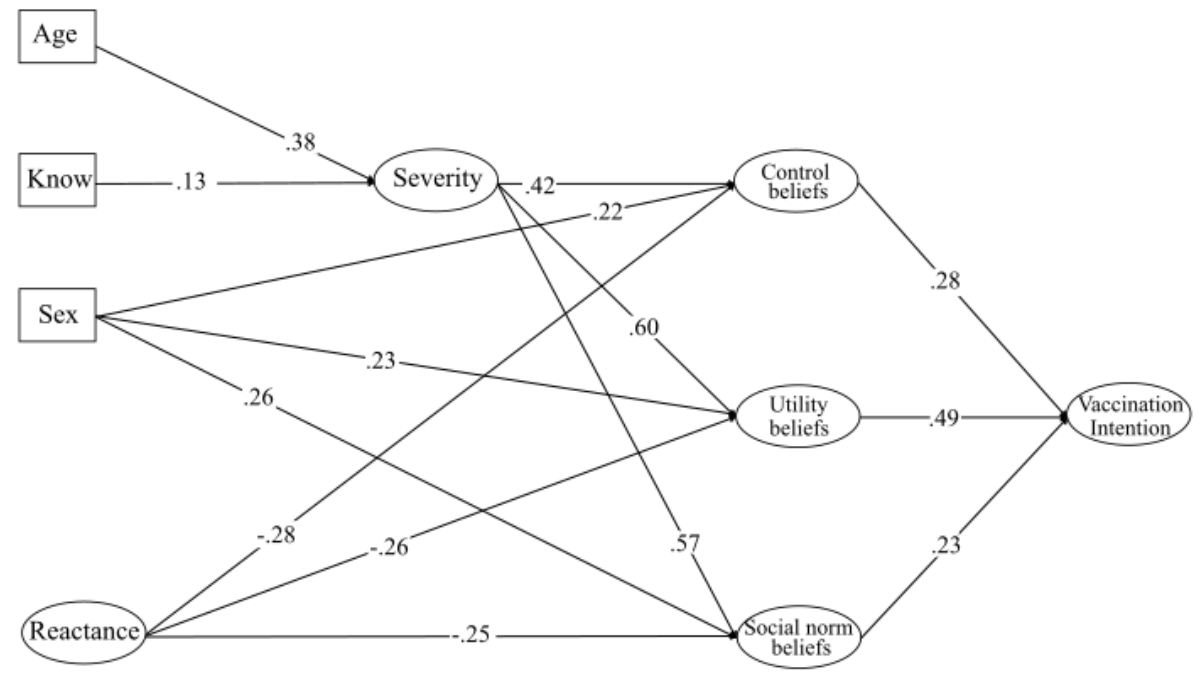

Note. Know $=$ Knowing someone afflicted with COVID-19 


\section{DETERMINANTS OF COVID-19 VACCINATION}

\section{Discussion}

Health communication that does not address central beliefs about vaccination will be ineffective in terms of increasing vaccination intention (Fishbein \& Ajzen, 2010). Our study contributes to the theoretical advancement of motivation to vaccinate, using TPB to identify crucial beliefs about vaccination intention and its antecedents. Insight into why people want to be vaccinated against COVID-19 or not, can facilitate the development of health communication that encourages vaccination. Our findings advance the understanding of the interplay between individual differences, such as reactance, perceived severity, age, gender, knowing someone afflicted with COVID-19, and TPB motivational factors, giving rise to the desire to be vaccinated. SEM analysis showed that all paths predicted by the TPB model were significant, as such our results extended existing knowledge about the determinants of willingness to vaccinate against COVID-19, as we found that people prone to reactance had lower intention to vaccinate because they had lower utility, control, and social beliefs. Older people and people who knew someone who had contracted COVID-19 perceived the disease to be more severe, and therefore had greater utility, control, and social beliefs, which, in turn, were related to greater motivation to be vaccinated. Men were more willing to be vaccinated than women as they had greater utility, control, and social beliefs, explaining the mechanism behind observed gender differences. Our findings have significant implications for the objectives, targets, and design of campaigns promoting vaccination against COVID-19.

Consistent with previous findings (Lueck \& Spiers, 2020), we demonstrated that utility, control, and social norm beliefs significantly predict the intention to vaccinate against COVID-19. This suggests that health communication should focus on vaccination benefits, applying more positive social norm beliefs, and increasing perceived control over vaccinations; 


\section{DETERMINANTS OF COVID-19 VACCINATION}

governments should publicly emphasize the benefits of vaccination and the disadvantages of non-vaccination. As perceived behavioral control improves with decreased uncertainty (Quintal et al., 2010), health communication can reduce uncertainty related to vaccination by providing information about the vaccination process. Another pathway to influence willingness to vaccinate against COVID-19 is to reinforce perceived positive social norm beliefs about vaccination. To this end, it may be worth encouraging people who have been vaccinated to upload positive social media posts (e.g., using relevant hashtags), and to convince undecided family members to get vaccinated.

We could not include moral norms in the examined model since analyses showed that the scale for moral norms did not measure a separate construct from the intention to vaccinate scale. The high correspondence between moral norms and intention to vaccinate suggests that vaccinating against COVID-19 during a pandemic was perceived as highly moral behavior. Further, an emphasis on the moral responsibility for the health of others (e.g., using the slogan "Protect others by vaccinating against COVID-19") may be an effective tool to promote vaccination.

In line with previous findings (Hornsey et al., 2018; Soveri et al., 2021), reactance was found to be a significant predictor of intention to vaccinate. A unique contribution of the current study is that we demonstrated that higher reactance had direct negative effects on all TPB components, which subsequently led to lower vaccination intention. We believe external pressures from governmental campaigns influenced lower vaccination willingness among individuals prone to high reactance; in opposition to such pressures, people with high reactance perceived lower utility, control, and social norm beliefs. The identification of reactance as a significant predictor of willingness to be vaccinated against COVID-19, allows for a range of 


\section{DETERMINANTS OF COVID-19 VACCINATION}

empirically validated measures of reactance reduction to be applied in campaigns promoting vaccination; for example, by framing encouragement messages in terms of vaccination-related gains, and losses associated with not being vaccinated (Shen, 2015). Further, to persuasively mitigate reactance, messages should contain information that remind people of their freedom of choice (Brehm \& Brehm, 1981). One persuasive strategy is to reverse the situation so that an individual perceives vaccination to increase freedom of choice, for instance, by pointing out that vaccination will provide freedom from pandemic-related restrictions, or by convincing people that the anti-vaccine movement restricts their freedom of choice to vaccinate by spreading false information about its effects (Hornsey et al., 2018).

Our study is unique in that it identifies the mechanism underlying the relationship between perceived severity of COVID-19 and intention to vaccinate using the TPB model, and identified the determinants of perceived severity, namely age and knowing someone afflicted with COVID-19. Perceived severity was related to more favorable attitudes toward vaccination, more perceived social pressure to vaccinate, and perceiving the vaccination process to be easy, thereby improving vaccination intention. By incorporating reactance and perceived severity of COVID-19 in a single model to explain the intention to vaccinate, we suggest that public health campaigns aiming to increase COVID-19 vaccination rates should emphasize the severity of the disease, while simultaneously avoiding overly aggressive forms of persuasion to encourage vaccination, as a backfire effect can occur in highly reactant individuals. Thus, a targeted approach to vaccination promotion may be effective.

In line with previous studies, we have demonstrated that older people perceived greater COVID-19 severity and were more willing to be vaccinated (Li et al., 2020; Makhanova \& Shepherd, 2020) than younger people. We contributed to existing literature by showing that older 


\section{DETERMINANTS OF COVID-19 VACCINATION}

people's perception of COVID-19 as a highly severe disease is related to their perceived higher utility, control, and social beliefs, compared to younger people. Convincing younger people that the disease is truly severe might more successfully persuade them to get vaccinated.

Our study extends the literature (Schwarzinger et al., 2021) by finding that people who knew someone afflicted by COVID-19 perceived the disease as more severe than those who did not. It is possible that familiarity with a person who contracted COVID-19 lends credibility to media reports on the severity of the disease. Knowing someone afflicted with COVID-19 was associated with a more positive attitude toward vaccination, perceived social expectations to be vaccinated, and greater perceived behavioral control, compared to not knowing someone who had been diagnosed, suggesting that people living in regions not badly affected by the pandemic should receive targeted encouragement to vaccinate.

Consistent with previous findings, we found that women were more likely to receive COVID-19 vaccination (Karlsson et al., 2020). In contrast with previous studies (Li et al., 2020; Makhanova \& Shepherd, 2020), however, our results showed that women and men evaluated the severity of COVID-19 similarly. The relationships between gender, perceived severity of the disease, and intention to vaccinate appear to be complex and sample-specific. Our study explained the mechanism of gender differences in intention to vaccinate by TPB components; relative to men, women perceived lower utility, control, and social norm beliefs. Addressing beliefs included in the TPB model may resolve gender differences.

\subsection{Limitation and Directions for Future Studies}

Our study has several limitations, as well as implications for future research. First, to participate in the study, participants needed access to the Internet and were thus drawn from a wealthier population with a higher educational background than the general populace, which 


\section{DETERMINANTS OF COVID-19 VACCINATION}

may have caused sample bias. Second, this study did not measure actual behavior, but declared intention of being vaccinated in the future, although it is worth noting that behavioral intention is a significant predictor of actual future behavior (Randall \& Wolff, 1994). Prospective studies should address the relationship between TPB components and actual COVID-19 vaccinations. Third, our study employed a cross-sectional design; causal interpretations using self-report measures are impossible, nor was it possible to assess changes over time. Future research should address these limitations through longitudinal studies.

\section{Acknowledgements}

This work was supported by the grant competition Research on COVID-19 (XXX, XXX).

\section{Supplementary material}

Supplementary File 1 Polish and English versions of the survey

Supplementary Table 1S Demographic data of the participants

Supplementary Table 2S Means, standard deviations, factor loadings for CFA and SEM

Supplementary Table 3S Spearman's rho correlations, means, standard deviations, and average variance extracted

Supplementary Table 4S Heterotrait-monotrait ratio of correlations

Supplementary Table 5S Model effects 


\section{DETERMINANTS OF COVID-19 VACCINATION}

\section{References}

Ajzen, I. (1991). The theory of planned behavior. Organizational Behavior and Human Decision Processes, 50, 179-211. doi: 10.1016/0749-5978(91)90020-T

Agarwal, V. (2014). A/H1N1 vaccine intentions in college students: An application of the theory of planned behavior. Journal of American College Health, 62(6), 416-424. doi: 10.1080/07448481.2014.917650.

Brehm. S. S. \& Brehm. J. W. (1981). Psychological reactance: A theory of freedom and control. San Diego. CA: Academic Press.

Conner, M., \& Armitage, C. J. (1998). Extending the theory of planned behavior: A review and avenues for further research. Journal of Applied Social Psychology, 28(15), 1429-1464. doi:10.1111/j.1559-1816.1998.tb01685.x

Dillard, J. P., \& Shen, L. (2005). On the nature of reactance and its role in persuasive health communication. Communication Monographs, 72(2), 144-168. doi: $10.1080 / 03637750500111815$

Drążkowski, D., Trepanowski, R., Chwiłkowska, P., \& Majewska, M. (2020). Self-persuasion increases motivation for social isolation during the COVID-19 pandemic through moral obligation. Social Psychological Bulletin, 15(4), 1-20. doi: /10.32872/spb.4415.

Fishbein, M., \& Ajzen, I. (2010). Predicting and changing behavior: The reasoned action approach. New York, NY: Psychology Press.

Fornell, C., \& Larcker, D. F. (1981). Structural equation models with unobservable variables and measurement error: Algebra and statistics Journal of Marketing Research, 18(3), 382-388. Doi: 10.1177/002224378101800313.

Henseler, J., Ringle, C. M., Sarstedt, M. (2015). A new criterion for assessing discriminant validity in variance-based structural equation modelling. Journal of the Academy of Marketing Science, 43(1), 115-135. doi: 10.1007/s11747-014-0403-8. 


\section{DETERMINANTS OF COVID-19 VACCINATION}

Hong, S.-M., \& Faedda, S. (1996). Refinement of the Hong Psychological Reactance Scale. Educational and Psychological Measurement, 56(1), 173-182. Doi: $10.1177 / 0013164496056001014$.

Hornsey, M. J., Harris, E. A., \& Fielding, K. S. (2018). The psychological roots of anti-vaccination attitudes: A 24-nation investigation. Health Psychology, 37(4), 307-315. doi: $10.1037 /$ hea0000586.

Hu, L., \& Bentler, P. M. (1999). Cutoff criteria for fit indexes in covariance structure analysis: Conventional criteria versus new alternatives. Structural Equation Modeling: A Multidisciplinary Journal, 6(1), 1-55. doi: 10.1080/10705519909540118

IRBIS, 2021.

Online

source:

https://www.onet.pl/informacje/onetwiadomosci/koronawirus-sondaz-ilu-polakow-chcesie-zaszczepic-przeciwko-covid-19/rf38dgg,79cfc278

Juraskova, I., O’Brien, M., Mullan, B., Bari, R., Laidsaar-Powell, R., \& McCaffery, K. (2012). HPV Vaccination and the Effect of Information Framing on Intentions and Behaviour: An Application of the Theory of Planned Behaviour and Moral Norm. International Journal of Behavioral Medicine, 19(4), 518-525. doi:10.1007/s12529-011-9182-5

Karlsson, L. C., Soveri, A., Lewandowsky, S., Karlsson, L., Karlsson, H., Nolvi, S., ... \& Antfolk, J. (2021). Fearing the disease or the vaccine: The case of COVID-19. Personality and Individual Differences, 172, 110590. doi: 10.1016/j.paid.2020.110590

Kim, J. H., Marks, F., \& Clemens, J. D. (2021). Looking beyond COVID-19 vaccine phase 3 trials. Nature Medicine, 27(2), 205-211. doi: 10.1038/s41591-021-01230-y

Li, J. B., Yang, A., Dou, K., Wang, L. X., Zhang, M. C., \& Lin, X. Q. (2020). Chinese public's knowledge, perceived severity, and perceived controllability of the COVID-19 and their associations with emotional and behavioural reactions, social participation, and precautionary behaviour: A national survey. BCM Public Health. doi:10.21203/rs.3.rs-16572/v2 


\section{DETERMINANTS OF COVID-19 VACCINATION}

Lueck, J. A., \& Spiers, A. (2020). Which Beliefs Predict Intention to Get Vaccinated against COVID-19? A Mixed-Methods Reasoned Action Approach Applied to Health Communication. Journal of Health Communication, 25(10), 790-798. doi: $10.1080 / 10810730.2020 .1865488$

Makhanova, A., \& Shepherd, M. A. (2020). Behavioral immune system linked to responses to the threat of COVID-19. Personality and Individual Differences, 167, 110221. Doi: 10.1016/j.paid.2020.110221.

Manstead, A. S. R. (2000). The role of moral norm in the attitude-behavior relation. In D. J. Terry \& M. A. Hogg (Eds.), Attitudes, behavior, and social context: The role of norms and group membership. Applied social research (pp. 11-30). Mahwah, NJ: Lawrence Erlbaum Associates, Publishers.

Moshagen, M., \& Musch, J. (2014). Sample size requirements of the robust weighted least squares estimator for confirmatory factor analysis with ordinal data. Methodology: European Journal of Research Methods for the Behavioral and Social Sciences, 10, 60-70. Doi: 10.1027/1614-2241/a00006.

Quintal, V. A., Lee, J. A., \& Soutar, G. N. (2010). Risk, uncertainty and the theory of planned behavior: A tourism example. Tourism Management, 31(6), 797-805. doi:10.1016/j.tourman.2009.08.006

R Core Team (2020). R: A language and environment for statistical computing. Vienna, Austria:

R Foundation for Statistical Computing. http://www.R-project.org/. [computer software].

Randall, D. M., \& Wolff, J. A. (1994). The time interval in the intention-behaviour relationship: Meta-analysis. British Journal of Social Psychology, 33(4), 405-418. doi: 10.1111/j.2044-8309.1994.tb01037.x

Rosseel, Y. (2012). lavaan: An R Package for Structural Equation Modeling. Journal of Statistical Software, 48(2), 1-36. http://www.jstatsoft.org/v48/i02/.

Schwarzinger, M., Watson, V., Arwidson, P., Alla, F., \& Luchini, S. (2021). COVID-19 vaccine hesitancy in a representative working-age population in France: a survey experiment 


\section{DETERMINANTS OF COVID-19 VACCINATION}

based on vaccine characteristics. The Lancet Public Health, 6(4), e210-e221. doi: $10.1016 / \mathrm{S} 2468-2667(21) 00012-8$

Soveri, A., Karlsson, L. C., Antfolk, J., Lindfelt, M., \& Lewandowsky, S. (2020). Unwillingness to engage in behaviors that protect against COVID-19: Conspiracy, trust, reactance, and endorsement of complementary and alternative medicine. doi: 0.31234/osf.io/mhetf

Steiger, J. H. (2007). Understanding the limitations of global fit assessment in structural equation modeling. Personality and Individual Differences, 42(5), 893-898. doi:10.1016/j.paid.2006.09.017

Thomson, A., Robinson, K., \& Vallée-Tourangeau, G. (2016). The 5As: A practical taxonomy for the determinants of vaccine uptake. Vaccine, 34(8), 1018-1024. doi: 10.1016/j.vaccine.2015.11.065

Yamey, G., Schäferhoff, M., Hatchett, R., Pate, M., Zhao, F., \& McDade, K. K. (2020). Ensuring global access to COVID-19 vaccines. The Lancet, 395(10234), 1405-1406. doi: $10.1016 / \mathrm{S} 0140-6736(20) 30763-7$ 


\section{DETERMINANTS OF COVID-19 VACCINATION}

Supplementary Materials to: Reactance and perceived disease severity as determinants of COVID-19 vaccination intention: An application of the theory of planned behavior

Supplementary File 1. Polish and English versions of the questionnaires

\section{A. Measures used in the study (in English and in Polish)}

\section{Severity of COVID-19}

\section{English}

1. I think that COVID-19 is a severe and dangerous sickness.

2. If I ever got sick with COVID-19, it could be dangerous to my life.

3. If I ever got sick with COVID-19, the course of this disease could be severe.

\section{Polish}

1. Uważam że COVID-19 jest ciężką i niebezpieczną chorobą.

2. Jeśli zachorowałbym/zachorowałabym na COVID-19, to mogłoby być to niebezpieczne dla mojego życia.

3. Jeśli zachorowałbym/zachorowałabym na COVID-19, to przebieg tej choroby mogłyby mieć ciężki charakter.

\section{Trait reactance (11 item version, as in Hong, \& Faedda (1996))}

\section{English}

1. Regulations trigger a sense of resistance in me.

2. I find contradicting others stimulating.

3. When something is prohibited, I usually think, "That's exactly what I am going to do."

4. I consider advice from others to be an intrusion.

5. I become frustrated when I am unable to make free and independent decisions.

6. It irritates me when someone points out things which are obvious to me.

7. I become angry when my freedom of choice is restricted. Reactance to compliance

8. Advice and recommendations usually induce me to do just the opposite.

9. I resist the attempts of others to influence me.

10. It makes me angry when another person is held up as a role model for me to follow.

11. When someone forces me to do something, I feel like doing the opposite.

\section{Polish}

1. Odgórne regulacje wyzwalają we mnie chęć oporu

2. Przeciwstawianie się innym jest dla mnie stymulujące

3. Kiedy coś jest zakazane, zwykle myślę: "Właśnie to zamierzam zrobić" 


\section{DETERMINANTS OF COVID-19 VACCINATION}

4. Uważam rady innych za narzucanie się

5. Czuję się sfrustrowany-a, gdy nie jestem w stanie podejmować wolnych i niezależnych decyzji

6. Irytuję się, gdy ktoś zwraca uwagę na rzeczy, które są dla mnie oczywiste

7. Odczuwam złość, gdy moja wolność wyboru jest ograniczona

8. Porady i rekomendacje zwykle skłaniają mnie do zrobienia czegoś wręcz przeciwnego

9. Opieram się próbom wpływania na mnie przez innych ludzi

10. Denerwuje mnie, gdy inna osoba jest przedstawiana mi jako wzór, który powinienem/powinnam naśladować

11. Kiedy ktoś zmusza mnie do zrobienia czegoś, czuję, że zrobię coś przeciwnego

\section{Attitude}

\section{English}

Getting vaccinated against COVID-19 seems to me, to be:

1. very stupid 1234567 very wise

2. unprotective 1234567 protective

3. very harmful 1234567 very beneficial

\section{Polish}

Zaszczepienie się na COVID-19 wydaje mi się:

1. bardzo głupie 1234567 bardzo rozsądne

2. nieochraniające 1234567 bardzo ochraniające

3. bardzo szkodliwe 1234567 bardzo korzystne

\section{Behavioural control}

\section{English}

1. If I wanted to, I could go to a medical facility with no problems whatsoever and get vaccinated, when that becomes possible.

completely disagree 1234567 completely agree

2. It's mostly up to me, whether I get vaccinated against COVID-19 when a vaccine becomes available. completely disagree 1234567 completely agree

3. Getting vaccinated against COVID-19 would be for me:

very hard 1234567 very easy

4. How much control will you have over getting vaccinated against COVID-19?

no control at all 1234567 full control

Polish 


\section{DETERMINANTS OF COVID-19 VACCINATION}

1. Gdybym chciał/-a mógłbym/mogłabym bez najmniejszego problemu udać się do placówki medycznej i zaszczepić się przeciw COVID-19, kiedy będzie to już możliwe.

zupełnie się nie zgadzam 1234567 całkowicie się zgadzam

2. To przede wszystkim do mnie należy decyzja, czy zaszczepię się przeciw COVID-19, kiedy będzie to już możliwe.

zupełnie się nie zgadzam 1234567 całkowicie się zgadzam

3. Zaszczepienie się przeciw COVID-19, kiedy będzie to już możliwe, byłoby dla mnie:

bardzo trudne 1234567 bardzo łatwe

4. Jaką kontrolę będziesz miał/a nad zaszczepieniem się na COVID-19?

brak kontroli 1234567 pełna kontrola

\section{Social norms}

\section{English}

1. Most of the people, who are of importance to me, would praise me for self-vaccinating against COVID-19.

2. Most of the people important to me would probably think I should get vaccinated against COVID-19.

3. People whose opinion I care about would say that it is a good idea for me to get vaccinated against COVID-19.

\section{Polish}

1) Większość osób, które są dla mnie ważne, pochwaliłaby mnie za zaszczepienie się na COVID-19.

2) Większość ważnych dla mnie ludzi zapewne uznałaby, że powinienem/powinnam zaszczepić się na COVID-19.

3) Ludzie, na których opinii mi zależy, stwierdziliby, że to dobry pomysł, abym za zaszczepił się na COVID-19.

\section{Moral norms}

\section{English}

1. I feel personally accountable for reducing the risk of infecting others during the COVID-19 pandemic by self-vaccinating.

2. Getting vaccinated against COVID-19 should be a moral obligation for all people.

3. Responsible behavior toward others, especially the sick and elderly, requires that I get vaccinated against COVID-19 when that becomes possible.

\section{Polish}

1) Czuję się osobiście odpowiedzialny/a za ograniczenie ryzyka zakażenia innych osób poprzez za zaszczepienie się na COVID-19, kiedy będzie to już możliwe.

2) Zaszczepienie się na COVID-19 powinno być moralnym obowiązkiem wszystkich ludzi. 


\section{DETERMINANTS OF COVID-19 VACCINATION}

3) Odpowiedzialne zachowanie wobec innych osób, zwłaszcza osób chorych i starszych, wymaga abym zaszczepił się na COVID-19, kiedy będzie to już możliwe

\section{Self-vaccination intention}

\section{English}

When the COVID-19 vaccine becomes available I intend to:

1. Search for information as of where, when and how I can get vaccinated against COVID-19.

2. Make an appointment at a medical facility in order to get vaccinated against COVID-19.

3. Vaccinate myself against COVID-19.

\section{Polish}

Gdy będzie dostępna szczepionka na koronawirusa zamierzam:

1. Poszukać informacji na temat tego, gdzie, kiedy i w jaki sposób mogę zaszczepić się przeciw COVID-19

2. Umówić się na wizytę w placówce medycznej w celu zaszczepienia się przeciw COVID-19.

3. Zaszczepić się przeciw COVID-19.

Supplementary Table 1S Demographic data of the participants

\begin{tabular}{lll}
\hline Descriptive variable & $\mathrm{n}$ & $\%$ \\
\hline Age $(M=45.34 ; S D=14.09)$ & 107 & 19.4 \\
$18-30$ & 108 & 19.6 \\
$31-40$ & 111 & 20.1 \\
$41-50$ & 115 & 20.9 \\
$51-60$ & 88 & 16.0 \\
$61-65$ & 22 & 4.0 \\
$66+$ & & \\
Sex & 276 & 50.1 \\
Male & 275 & 49.9 \\
Female & & \\
Education & 12 & 2.2 \\
Elementary & 54 & 9.8 \\
Occupational & 188 & 34.1 \\
Middle & 75 & 13.6 \\
Post-secondary education & 44 & 8.0 \\
Bachelor's & 178 & 32.3 \\
Higher & & \\
Residence & 194 & 35.2 \\
Village & 66 & 12.0 \\
Small city (less than 20000 residents) & 109 & 19.8 \\
Medium city (20-99 thousand residents) & 106 & 19.2 \\
Big city (100-500 thousand residents) & 76 & 13.8 \\
Very big city (over 500000 residents) & &
\end{tabular}




\section{DETERMINANTS OF COVID-19 VACCINATION}

Have you gotten sick with COVID-19?

$\begin{array}{lll}\text { No } & 501 & 90.9 \\ \text { Yes } & 50 & 9.1\end{array}$

Do you personally know someone who has gotten sick with COVID-19?

$\begin{array}{lll}\text { No } & 162 & 29.4 \\ \text { Yes } & 388 & 70.4 \\ \text { I don't know } & 1 & .2\end{array}$

Supplementary Table 2S Means, standard deviations, factor loadings for CFA and SEM

\begin{tabular}{|c|c|c|c|c|c|}
\hline \multirow[t]{2}{*}{ Factor } & \multirow[t]{2}{*}{ Item } & \multirow[t]{2}{*}{ Mean } & \multirow[t]{2}{*}{$\mathrm{SD}$} & \multicolumn{2}{|c|}{ Factor Loading } \\
\hline & & & & CFA & SEM \\
\hline \multirow[t]{11}{*}{ Reactance } & $\mathrm{R} 1$ & 4.26 & 1.41 & .832 & .783 \\
\hline & $\mathrm{R} 2$ & 3.71 & 1.24 & .555 & .568 \\
\hline & R3 & 3.34 & 1.40 & .571 & .580 \\
\hline & $\mathrm{R} 4$ & 4.62 & 1.29 & .642 & .632 \\
\hline & R5 & 4.68 & 1.35 & .705 & .718 \\
\hline & R6 & 4.87 & 1.29 & .480 & .517 \\
\hline & R7 & 5.03 & 1.37 & .651 & .662 \\
\hline & $\mathrm{R} 8$ & 3.61 & 1.31 & .720 & .720 \\
\hline & R9 & 4.56 & 1.28 & .745 & .741 \\
\hline & $\mathrm{R} 10$ & 4.76 & 1.36 & .656 & .668 \\
\hline & R11 & 4.12 & 1.28 & .738 & .747 \\
\hline \multirow[t]{3}{*}{ Severity } & Se1 & 5.30 & 1.43 & .990 & .974 \\
\hline & $\mathrm{Se} 2$ & 5.12 & 1.48 & .850 & .861 \\
\hline & $\mathrm{Se} 3$ & 5.00 & 1.47 & .852 & .859 \\
\hline \multirow[t]{3}{*}{ Intention } & I1 & 4.48 & 1.80 & .904 & .899 \\
\hline & $\mathrm{I} 2$ & 4.19 & 1.82 & .966 & .969 \\
\hline & $\mathrm{I} 3$ & 4.17 & 1.87 & .975 & .976 \\
\hline \multirow[t]{3}{*}{ Utility beliefs } & U1 & 4.63 & 1.87 & .960 & .951 \\
\hline & $\mathrm{U} 2$ & 4.41 & 1.79 & .921 & .913 \\
\hline & $\mathrm{U} 3$ & 4.27 & 1.78 & .891 & .885 \\
\hline \multirow[t]{4}{*}{ Control beliefs } & $\mathrm{C} 1$ & 4.49 & 1.64 & .858 & .847 \\
\hline & $\mathrm{C} 2$ & 5.66 & 1.31 & .054 & - \\
\hline & C3 & 4.35 & 1.69 & .904 & .894 \\
\hline & $\mathrm{C} 4$ & 4.67 & 1.75 & .444 & .447 \\
\hline Social norm & $\mathrm{S} 1$ & 4.21 & 1.56 & .937 & .939 \\
\hline \multirow[t]{2}{*}{ beliefs } & S2 & 4.25 & 1.57 & .945 & .941 \\
\hline & S3 & 4.21 & 1.57 & .972 & .969 \\
\hline & M1 & 4.36 & 1.67 & .911 & - \\
\hline \multirow[t]{2}{*}{ beliefs } & M2 & 4.20 & 1.81 & .945 & - \\
\hline & M3 & 1.72 & 1.72 & .964 & - \\
\hline
\end{tabular}




\section{DETERMINANTS OF COVID-19 VACCINATION}

Supplementary Table 3S Spearman's rho correlations, means, standard deviations, and average variance extracted

\begin{tabular}{|c|c|c|c|c|c|c|c|c|c|c|}
\hline & 1 & 2 & 3 & 4 & 5 & 6 & 7 & 8 & 9 & 10 \\
\hline 1. Reactance & - & & & & & & & & & \\
\hline 2. Severity & $-.13 * *$ & - & & & & & & & & \\
\hline 3. Intention & $-.20 * * *$ & $.51 * * *$ & - & & & & & & & \\
\hline 4. Utility beliefs & $-.20 * * *$ & $.52 * * *$ & $.84 * * *$ & - & & & & & & \\
\hline 5. C. beliefs ${ }^{l}$ & $-.12 * *$ & $.38 * * *$ & $.69 * * *$ & $.62 * * *$ & - & & & & & \\
\hline 6. S.n. beliefs ${ }^{2}$ & $-.18 * * *$ & $49 * * *$ & $.81 * * *$ & $.80 * * *$ & $.59 * * *$ & - & & & & \\
\hline 7. M.n. beliefs ${ }^{3}$ & $-.19 * * *$ & $.53 * * *$ & $.90 * * *$ & $.85 * * *$ & $.65 * * *$ & $.84 * * *$ & - & & & \\
\hline 8. Sex & -.02 & -.01 & $.23 * * *$ & $.22 * * *$ & $.15 * * *$ & $.26^{* * *}$ & $.24 * * *$ & - & & \\
\hline 9. Age & -.03 & $.36 * * *$ & $.22 * * *$ & $.20 * * *$ & $.15 * * *$ & $.18 * * *$ & $.22 * * *$ & .04 & - & \\
\hline 10. Know $^{2}$ & -.02 & $.09 *$ & .07 & $.11 * *$ & $.15 * * *$ & .06 & .05 & $-.08 *$ & -.08 & - \\
\hline$M$ & 4.23 & 5.14 & 4.28 & 4.44 & 4.79 & 4.22 & 4.30 & .50 & 45.34 & .70 \\
\hline$S D$ & .94 & 1.36 & 1.77 & 1.72 & 1.15 & 1.52 & 1.67 & .50 & 14.09 & .46 \\
\hline$A V E$ & .45 & .81 & .90 & .86 & .47 & .90 & .88 & - & - & - \\
\hline$\sqrt{ } A V E$ & .67 & .90 & .95 & .92 & .69 & .95 & .94 & - & - & - \\
\hline
\end{tabular}

Note. Sex was dummy coded such that $1=$ women and $2=$ men; Know coded as $0=$ No, $1=$ Yes

$* p<.05, * * p<.01, * * * p<.001$

${ }^{1}$ Control beliefs, ${ }^{2}$ Social norm beliefs, ${ }^{3}$ Moral norm beliefs ${ }^{4}$ Knowing someone afflicted with COVID-19

Supplementary Table 4S Heterotrait-monotrait ratio of correlations

\begin{tabular}{|c|c|c|c|c|c|c|c|}
\hline & 1 & 2 & 3 & 4 & 5 & 6 & 7 \\
\hline 1. Reactance & - & & & & & & \\
\hline 2. Severity & .18 & - & & & & & \\
\hline 3. Intention & .26 & .56 & - & & & & \\
\hline 4. Utility beliefs & .26 & .58 & .88 & - & & & \\
\hline 5. C. beliefs ${ }^{1}$ & .32 & .46 & .79 & .73 & - & & \\
\hline 6. S.n. beliefs ${ }^{2}$ & .23 & .55 & .84 & .83 & .72 & - & \\
\hline 7. M.n. beliefs ${ }^{3}$ & .25 & .59 & .94 & .89 & .76 & .88 & - \\
\hline
\end{tabular}

${ }^{1}$ Control beliefs, ${ }^{2}$ Social norm beliefs, ${ }^{3}$ Moral norm beliefs

\section{Supplementary Table 5S Model effects}

\begin{tabular}{lllll}
\hline $\mathrm{N}$ & \multicolumn{1}{c}{ Variables } & \multicolumn{1}{c}{$\begin{array}{c}\text { Direct effect } \\
(\mathrm{p} \text {-value })\end{array}$} & \multicolumn{1}{c}{$\begin{array}{c}\text { Indirect effect } \\
(\mathrm{p} \text {-value })\end{array}$} & $\begin{array}{c}\text { Total effect } \\
(\mathrm{p} \text {-value })\end{array}$ \\
\hline 1 & $\mathrm{Sx} \rightarrow \mathrm{Se}$ & -.016 & - & -.016 \\
2 & $\mathrm{Sx} \rightarrow \mathrm{S}$ & $.257^{* * *}$ & - & $.248^{* * *}$ \\
& $\mathrm{Sx} \rightarrow \mathrm{Se} \rightarrow \mathrm{S}$ & - & -.009 & - \\
3 & $\mathrm{Sx} \rightarrow \mathrm{U}$ & $.230^{* * *}$ & - & $.220^{* * *}$ \\
& $\mathrm{Sx} \rightarrow \mathrm{Se} \rightarrow \mathrm{U}$ & - & -.010 & - \\
4 & $\mathrm{Sx} \rightarrow \mathrm{C}$ & $.223^{* * *}$ & - & $.216^{* * *}$ \\
& $\mathrm{Sx} \rightarrow \mathrm{Se} \rightarrow \mathrm{C}$ & - & -.007 & - \\
& $\mathrm{Sx} \rightarrow \mathrm{I}$ & - & - & - \\
& $\mathrm{Sx} \rightarrow \mathrm{S} \rightarrow \mathrm{I}$ & - & $.058^{* *}$ & - \\
& $\mathrm{Sx} \rightarrow \mathrm{Se} \rightarrow \mathrm{S} \rightarrow \mathrm{I}$ & - & -.002 & -
\end{tabular}




\begin{tabular}{|c|c|c|c|c|}
\hline & $\mathrm{Sx} \rightarrow \mathrm{U} \rightarrow \mathrm{I}$ & - & $.113 * * *$ & - \\
\hline & $\mathrm{Sx} \rightarrow \mathrm{Se} \rightarrow \mathrm{U} \rightarrow \mathrm{I}$ & - & -.005 & - \\
\hline & $\mathrm{Sx} \rightarrow \mathrm{C} \rightarrow \mathrm{I}$ & - & $.063 * *$ & - \\
\hline & $\mathrm{Sx} \rightarrow \mathrm{Se} \rightarrow \mathrm{C} \rightarrow \mathrm{I}$ & - & -.002 & - \\
\hline 6 & $\mathrm{~K} \rightarrow \mathrm{Se}$ & $.126^{* *}$ & - & $.126^{* *}$ \\
\hline \multirow[t]{2}{*}{7} & $\mathrm{~K} \rightarrow \mathrm{S}$ & .022 & - & $.093 *$ \\
\hline & $\mathrm{K} \rightarrow \mathrm{Se} \rightarrow \mathrm{S}$ & - & $.071 * *$ & - \\
\hline \multirow[t]{2}{*}{8} & $\mathrm{~K} \rightarrow \mathrm{A}$ & .064 & - & $.139 * *$ \\
\hline & $\mathrm{K} \rightarrow \mathrm{Se} \rightarrow \mathrm{U}$ & - & $.075^{* *}$ & - \\
\hline \multirow[t]{2}{*}{9} & $\mathrm{~K} \rightarrow \mathrm{C}$ & .057 & - & $.111^{* *}$ \\
\hline & $\mathrm{K} \rightarrow \mathrm{Se} \rightarrow \mathrm{C}$ & - & $.054 * *$ & - \\
\hline \multirow[t]{7}{*}{10} & $\mathrm{~K} \rightarrow \mathrm{I}$ & - & - & - \\
\hline & $\mathrm{K} \rightarrow \mathrm{S} \rightarrow \mathrm{I}$ & - & .005 & - \\
\hline & $\mathrm{K} \rightarrow \mathrm{Se} \rightarrow \mathrm{S} \rightarrow \mathrm{I}$ & - & $.016^{*}$ & - \\
\hline & $\mathrm{K} \rightarrow \mathrm{U} \rightarrow \mathrm{I}$ & - & .032 & - \\
\hline & $\mathrm{K} \rightarrow \mathrm{Se} \rightarrow \mathrm{U} \rightarrow \mathrm{I}$ & - & $.037 * *$ & - \\
\hline & $\mathrm{K} \rightarrow \mathrm{C} \rightarrow \mathrm{I}$ & - & .016 & - \\
\hline & $\mathrm{K} \rightarrow \mathrm{Se} \rightarrow \mathrm{C} \rightarrow \mathrm{I}$ & - & $.015 *$ & - \\
\hline 11 & $\mathrm{Ag} \rightarrow \mathrm{Se}$ & $.376 * * *$ & - & $.376^{* * *}$ \\
\hline \multirow[t]{2}{*}{12} & $\mathrm{Ag} \rightarrow \mathrm{S}$ & -.026 & - & $.187 * * *$ \\
\hline & $\mathrm{Ag} \rightarrow \mathrm{Se} \rightarrow \mathrm{S}$ & - & $.214 * * *$ & - \\
\hline \multirow[t]{2}{*}{13} & $\mathrm{Ag} \rightarrow \mathrm{U}$ & -.003 & - & $.221 * * *$ \\
\hline & $\mathrm{Ag} \rightarrow \mathrm{Se} \rightarrow \mathrm{U}$ & - & $.225 * * *$ & - \\
\hline \multirow[t]{2}{*}{14} & $\mathrm{Ag} \rightarrow \mathrm{C}$ & .020 & - & $.180 * * *$ \\
\hline & $\mathrm{Ag} \rightarrow \mathrm{Se} \rightarrow \mathrm{C}$ & - & $.161 * * *$ & - \\
\hline \multirow[t]{7}{*}{15} & $\mathrm{Ag} \rightarrow \mathrm{I}$ & - & - & - \\
\hline & $\mathrm{Ag} \rightarrow \mathrm{S} \rightarrow \mathrm{I}$ & - & -.006 & - \\
\hline & $\mathrm{Ag} \rightarrow \mathrm{Se} \rightarrow \mathrm{S} \rightarrow \mathrm{I}$ & - & $.048 * *$ & - \\
\hline & $\mathrm{Ag} \rightarrow \mathrm{U} \rightarrow \mathrm{I}$ & - & -.001 & - \\
\hline & $\mathrm{Ag} \rightarrow \mathrm{Se} \rightarrow \mathrm{U} \rightarrow \mathrm{I}$ & - & $.111 * * *$ & - \\
\hline & $\mathrm{Ag} \rightarrow \mathrm{C} \rightarrow \mathrm{I}$ & - & .004 & - \\
\hline & $\mathrm{Ag} \rightarrow \mathrm{Se} \rightarrow \mathrm{C} \rightarrow \mathrm{I}$ & - & $.045^{* *}$ & - \\
\hline 16 & $\mathrm{Se} \rightarrow \mathrm{S}$ & $.568 * * *$ & - & $.568 * * *$ \\
\hline 17 & $\mathrm{Se} \rightarrow \mathrm{U}$ & $.597 * * *$ & - & $.597 * * *$ \\
\hline 18 & $\mathrm{Se} \rightarrow \mathrm{C}$ & $.428 * * *$ & - & $.428 * * *$ \\
\hline \multirow[t]{4}{*}{19} & $\mathrm{Se} \rightarrow \mathrm{I}$ & - & - & - \\
\hline & $\mathrm{Se} \rightarrow \mathrm{S} \rightarrow \mathrm{I}$ & - & $.128 * *$ & - \\
\hline & $\mathrm{Se} \rightarrow \mathrm{U} \rightarrow \mathrm{I}$ & - & $.294 * * *$ & - \\
\hline & $\mathrm{Se} \rightarrow \mathrm{C} \rightarrow \mathrm{I}$ & - & $.121 * *$ & - \\
\hline 20 & $\mathrm{R} \rightarrow \mathrm{S}$ & $-.246 * * *$ & - & $-.246 * * *$ \\
\hline 21 & $\mathrm{R} \rightarrow \mathrm{U}$ & $-.282 * * *$ & - & $-.282 * * *$ \\
\hline 22 & $\mathrm{R} \rightarrow \mathrm{C}$ & $-.258 * * *$ & - & $-.258 * * *$ \\
\hline 23 & $\mathrm{R} \rightarrow \mathrm{I}$ & - & - & - \\
\hline & $\mathrm{R} \rightarrow \mathrm{S} \rightarrow \mathrm{I}$ & - & $-.055^{* *}$ & - \\
\hline & $\mathrm{R} \rightarrow \mathrm{U} \rightarrow \mathrm{I}$ & - & $-.139 * * *$ & - \\
\hline & $\mathrm{R} \rightarrow \mathrm{C} \rightarrow \mathrm{I}$ & - & $-.073 * *$ & - \\
\hline 24 & $\mathrm{~S} \rightarrow \mathrm{I}$ & $.225^{* * *}$ & - & $.225^{* * *}$ \\
\hline 25 & $\mathrm{U} \rightarrow \mathrm{I}$ & $.492 * * *$ & - & $.492 * * *$ \\
\hline 26 & $\mathrm{C} \rightarrow \mathrm{I}$ & $.282 * * *$ & - & $.282 * * *$ \\
\hline
\end{tabular}




\section{DETERMINANTS OF COVID-19 VACCINATION}

Sx - Sex; K - Knowing someone afflicted with COVID-19; Ag - Age; Se - Severity; S - social norm beliefs; C - Control beliefs; U - utility beliefs; I - Self-vaccination intention; R - Reactance 